\title{
THE BIOLOGICAL COUNCIL: A PROGRESS REPORT
}

\author{
By DR. W. P. K. FINDLAY
}

$\mathrm{T}$ EN years have now passed since the first moves were made to bring into being an organization that would enable British scientific societies in the biological field to collaborate in matters of mutual concern, and it may be of interest to survey what has been achieved in this direction.

Many biologists had felt for some time that the activities of the specialized societies to which they belonged remained largely unknown to other biologists who happened to belong to different societies or associations, although often the activities of these other societies were of direct interest to them.

On the initiative of the Biochemical Society, representatives of some eight other societies attended an informal meeting on September 22, 1944, and agreed that steps should be taken to establish a co-ordinating committee consisting of representatives of the biological societies. Thus the Biological Council came into being in July 1945, and in November of the same year, at a meeting held under the chairmanship of Sir Henry Dale, its officers were appointed and a programme of activities suggested (Nature, 156,713 ; 1945).

One of the first tasks undertaken was the preparation of an annual calendar containing information about the affiliated societies and the dates of their meetings. This has appeared in one form or another each year since then, and has proved of great value to secretaries, who have thereby been able to avoid undesirable clashes in the dates of meetings of societies having similar interests.

In response to a demand from a number of biologists, a scheme was established in 1947 by which reprints of the titles of papers in the tables of contents of a group of journals were circulated soon after publication. This scheme ran quite successfully for a number of years; but it was discontinued in 1953 owing to an inadequate number of subscribers.

At the time when the Council was formed it was agreed that it should not concern itself with any professional matters affecting biologists themselves or their careers. A sharp cleavage of opinion was revealed at the early meetings when this subject was raised by certain delegates, and at that time it would have been fatal to the success of the Council if professional matters had figured on its agenda. However, in 1946 the Association of British Zoologists invited the Council to consider the need for an Institute of Biology, and the Institute officially came into being as an independent organization on January 5, 1950 (Nature, 165, 131 ; 1950). It was, however, felt that some continuing form of association between the two bodies was desirable and would lead to economies in the running of the Council business ; so, in 1951, the Council became an advisory scientific committee to the Institute, which undertook to carry out the routine secretarial work of the Council. This arrangement has since worked well and to the mutual advantage of both bodies. Following this reconstitution of the Council in 1952, Dr. W. P. K. Findlay was elected chairman, Prof. F. L. Warren honorary treasurer, and Dr. J. L. Cloudesley-Thompson honorary secretary. In 1954, Prof. C. T. Ingold became chairman.

Societies the membership of which approaches four figures often find that the amount of routine secre. tarial work becomes too much for honorary secretaries to handle, and recently several such societies affiliated to the Council have arranged for this work to be carried out by the staff of the Institute. The provision of such secretarial assistance in a central office was one of the original objects of the Council, and it is hoped that it will be possible to develop these facilities still further.

Several meetings have been held of the editors of the principal biological journals (including some that were not connected with the societies affiliated to the Council) to discuss problems of common interest. Among proposals that were submitted to the Council at an early date was one suggesting some form of conjoint publishing bureau that would hold stocks of reprints and distribute them to individuals. This received little support, and it was at once clear that societies regarded the complete independence of their journals as an exceedingly important principle. However, a number of useful suggestions were put forward at these meetings, on which action was afterwards taken. For example, many editors observed how much time had to be spent correcting literature citations in the manuscripts submitted to their journals, because these did not conform to the abbreviations given in the "World List of Scientific Periodicals". It was therefore decided that a selected list of the abbreviations of the titles of the biological journals to which reference is most frequently made should be prepared. Mr. R. W. Marsh, editor of the Annals of Applied Biology, kindly undertook this task and, with the co-operation of the "World List" authorities, a list was prepared and published in 1949 , a second edition following in 1954 .

In 1947 the Keeper of the Science Library sought the assistance of the Council in obtaining the consent of its associated societies to permit photocopying of copyright papers published in their journals. In general, a favourable response was forthcoming, and permission to reproduce photographically articles in all but the current issues was willingly accorded by most of the societies involved.

The poor delivery of scientific papers by inexperienced speakers often seriously detracts from their interest to the audience, so that accounts of fundamentally interesting work frequently do not receive the attention which they merit. Some "Notes for Speakers" were therefore prepared by the Biological Council in order to assist speakers at scientifio meetings in the same way as "Instructions to Contributors" are issued to guide authors contributing papers to scientific journals. These "Notes", which were first published in the Annals of Applied Biology in 1954, are available to members of the Institute of Biology and to members of affiliated societies.

An obvious duty of the Council is to promote joint discussions between societies and groups of biologists who are interested in similar problems in related. fields. The Council welcomed an invitation in 1951 from the Fine Chemicals Group of the Society of Chemical Industry to co-ordinate symposia on drug action, and a committee, under the chairmanship of Sir Charles Harington, was set up for this purpose. A number of highly successful symposia on subjects such as "Anticholinesterases", "Chemotherapy of 
Tuberculosis" and "Insecticides" have already been held.

The Council has been consulted on a number of occasions regarding various aspects of the teaching of biology, such, for example, as the teaching of human biology in schools, and it was asked to nominate a representative to serve on a national board to consider the recruitment and training of laboratory technicians.

Many other minor matters have been dealt with by the Council; but perhaps one of the most important incidental benefits which members have derived from attendance at its meetings has been the personal contact between the officers of various societies and associations.

\section{MEDICAL RESEARCH LABORATORY OF VOJVODINA, NOVI SAD, YUGOSLAVIA By DR. P. SCHWARZ Director}

$\mathrm{I}_{\mathrm{Y}}^{\mathrm{N}}$ 1947 it was announced in these columns ${ }^{1}$ that a Yugoslav State laboratory was to be founded in Novi Sad, with the task of dealing with problems of experimental biology and medicine. For certain administrative reasons the laboratory was transferred to Belgrade, and the director, Dr. P. Martinovitch, continued his research in the Boris Kidritch Institute of Nuclear Science, where there were convenient facilities for carrying out his work. The premises in Novi Sad and a part of the fittings and apparatus were taken over by a newly founded bacteriological and serological laboratory under my leadership, and the whole organization was named the Medical Research Laboratory of Vojvodina. This new Laboratory has fixed research tasks, and its budget is financed by the State.

Novi Sad is a relatively small town of 86,000 inhabitants, but notwithstanding is the cultural and administrative centre of a rather large territory containing about eight hundred medical practitioners. The idea arose that scientific research work should not be the privilege of a fortunate few, exclusively employed for this purpose in well-equipped laboratories with undisturbed working possibilities; the ordinary medical practitioner often has a creative idea, and it was proposed that an organization should be established with the task of preserving creative ideas and not letting them fall into oblivion. The state of medical conditions in Yugoslavia makes it imperative that this help should be given so as to develop ideas which are in close touch with practical questions of health and sanitation.

The Laboratory has therefore been created in two parts: one is the bacteriological and serological laboratory already mentioned, with full-time workers who are allotted research tasks; and the other is the 'service laboratory', where part-time laboratory workers are employed, with the task of helping physicians who are working out their ideas in their spare time. The management of the Laboratory investigates whether the idea is original, whether it has some relations to practical sanitary questions and whether the Laboratory is able, taking into account limitations of staff and finance, to help in carrying out the research. In the service department of the Laboratory the following part-time workers are employed : a pathologist, a bacteriologist, a hæmatologist, a biochemist, and a surgeon for carrying out operations on experimental animals. Besides these, the Laboratory employs assistants for part-time work according to the necessity and nature of the work. The above-mentioned sections are in the process of being formed and are at present only very modestly equipped; among other things, it is very difficult to get hold of medical publications and the periodical literature. It might be thought that, under such conditions, it is a mistake to undertake such a job and that it would be better to wait until matters improve. But to do so would be to risk losing ideas and losing the collaboration of ambitious young workers, and this would be an even greater mistake; so we have decided to work under the present conditions, even at the risk of publishing something in ignorance of the fact that the same work has been published elsewhere by others.

The Laboratory has proved to be an active organization, for since the time of its functioning in 1951 eight research workers have asked for help from its laboratory service and have worked on the following topics, publishing them in the Yugoslav medical press and also partly in foreign periodicals : the mechanism of blood clot retraction ${ }^{2}$; the determination of the value of the thrombocytes with regard to their function in blood clot retraction ${ }^{3}$; the determination of the serum protein fractions with the aid of salting out with ammonium sulphate* ; the fractionation of beef heart extract ${ }^{5}$; new methods of making serial dilutions with small gradations ${ }^{b}$; new methods for adjusting colloidal gold solutions and carrying out the colloidal gold test ${ }^{7}$; the nature of the process of fibrinolysis and the products of the decomposition of the fibrin ${ }^{8}$; serum proteins in pregnant women ${ }^{2}$; the estimation of blood plasma clotting and the relation of the calcium concentration to the first and the second phase of blood coagulation ${ }^{10}$; the therapy of miscarriage with histamine ${ }^{11}$; the finding of enhanced sensitivity of some Salmonella strains to bismuth and the preseription of a modification of the Wilson-Blair medium for the elimination of the inhibitory power of bismuth (balanced sulphite a.gar) ${ }^{13}$; experimental hyperfolliculinemy in dogs ${ }^{14}$; and experimental eclampsia in dogs ${ }^{15}$. Nearly all the papers enumerated in refs. 2-15 are written in Yugoslavian, but a translation or detailed summary will gladly be sent if requested. Besides these published papers, the following research problems have been registered at the Laboratory and are still under investigation: the disturbances of the antihæmorrhagic mechanism in dogs injured by X-rays; the nature of the $S$ factor of blood clot retraction; contribution to the pathogenesis of eclampsia; the investigation of the effect of the liver on cestrogen metabolism; the changes arising in the antihæmorrhagic mechanism caused by folliculin; the effect of cation combinations of the sulphite-reducing micro-organism; experiments on the quantitative estimation of the accessory growth factor; the effect of artificial hibernation on the incubation of some virus diseases.

The full-time part of the Laboratory has worked out experimentally the possibility of prepering desiccated culture media and has prepared an extract for the Meinicke clarification test. As a result of these investigations, the Laboratory has prepared a rather good desiccated Wilson-Blair agar on a small scale and, in addition, has fumished most of the $M$-antigen used in Yugoslavia. 